\title{
THE ORIGIN OF AMBERGRIS
}

\author{
Robert CLARKe
}

AвSTRACT: Early and modern theories of the origin of ambergris are described. Ambergris occurs in both male and female sperm whales, and also in the pygmy sperm whale. It occurs in about one in $100 \mathrm{sperm}$ whales. The largest find weighed $455 \mathrm{~kg}$ and sold for $£ 23,000$ in 1914 . Ambergris occurs in the rectum of the whale but neither causes nor betrays disease. The rectum is not damaged by squid beaks. Indigestible material, that is, squid beaks and pens and the cuticles of parasitic nematode worms, are regularly vomited by sperm whales and the intestine and rectum can only deal with liquid faeces. When, as sometimes happens, some indigestible material leaks into the intestine and, by at least partly blocking the flow of the faeces, the tangled mass is pushed into the rectum where there is reason to believe that the water absorbing capacity of the rectum is increased (p. 33). In this way the faecal matter is precipitated on the indigestible material to form a smooth concretion and the faeces can pass again. Then more foecal material arrives and the process is repeated. In this way the flow of liquid faeces is maintained, although at the expense of accretionary growth in size of the coprolith which becomes ambergris. Response processes in the whale are constructional. The biochemical processes which transform the coprolith into ambergris are consequential upon its incubation over a long period in the peculiar environment of the rectum teeming with bacteria. Eventually the rectum stretches until it breaks, causing the whale's death and the ambergris is released into the sea.

Resumen: Se describe antiguas y modernas teorías sobre el origen de ambar gris. Se encuentra ambar gris en cachalotes machos y hembras y también en el cachalote pigmeo. Ocurre en alrededor del uno por ciento de cachalotes. El hallazgo más grande pesó $455 \mathrm{~kg}$ y se vendió en 23,000 libras esterlinas en 1914. Ambar gris se encuentra en el recto del cachalote pero no causa ni revela enfermedad. El recto no es dañado por los picos de calamares. Material indigerible, es decir picos de calamares y sus plumas, y las cutículas de nemátodes parásitos, son vomitados regularmente por los cachalotes y el intestino y el recto pueden tratar solamente con heces líquidas. Cuando, como pasa de vez en cuando, algún material indigerible lograr pasar hasta el intestino, donde por lo menos parcialmente bloquea el flujo de las heces, esta masa enmarañada es empujada dentro del recto, donde hay razón para creer que la capacidad del recto para absorber agua aumenta (p. 33). De esta manera el material fecal es precipitado sobre el material indigerible para formar una concreción suave y las heces pueden pasar otra vez. Llega mas material fecal y el proceso se repite. De esta manera el flujo de las heces líquidas es mantenido, aunque a expensas del acrecentado aumento de tamaño del coprolito que llega a ser ambar gris. Procesos de respuesta en la ballena son estructurales. Los procesos bioquímicos que transforman el coprolito en ambar gris son consecuenciales de su incubación durante un largo periodo en el ambiente singular del recto saturado de bacterias. Eventualmente el recto se estira hasta que se rompe, causando la muerte de la ballena y el ambar gris es echado al mar.

Key words: Ambergris, sperm whale, pygmy sperm whale, faecal flow, rectal obstruction.

\section{Introduction}

In 1954 the ambergris merchant Bovill wrote 'Not many people know what ambergris is, but those who do know it is not the faeces of a whale.' I propose here to review known and new facts about the incidence, structure and constitution of ambergris, and from these argue that ambergris is indeed a faecal product of the sperm whale (Physeter catodon ${ }^{2}$ ), that it is, in a word, a coprolith.

Ambergris has been prized for over a thousand years as, medicine, condiment, aphrodisiac or perfume. Today it is still valuable in perfumery where it is the best fixative known, that is, according to a perfume chemist 'It preserves the note of a perfume after the perfume itself has departed.' Its origin has attracted speculation since ambergris was first mentioned early in the ninth century when an Arab traveller recorded trade in ambergris among the islands of the Indian Ocean (Kerr, 1811-1824, vol. 1, p. 49). Baudouin's claim (1911) that ambergris is known since the Stone Age is not supported by any valid evidence.

\section{Early theories of origin}

In the $17^{\text {th }}$ century, the age of the new scientists, speculation about ambergris was at its height. Chevalier (1700) described how a medal was struck in Amsterdam in 1694 to commemorate a precious boulder weighing $83 \mathrm{~kg}$, the gift from the King of Tidor in the Mollucas to the Dutch East India Company (Figure 1). In 1667 Klobius recorded 18 theories on the origin of ambergris. Leónard Fuschius said that ambergris was a fake or composite of labdanum, aloe-wood and civet (Gattefossé, 1920), a shrewd claim because labdanum and aloe-wood are still recognized as having the gamme ambrée (Janistyn, 1956) whilst civet would provide the animal note. Yet for others, recorded by the encyclopaedist Furetiére and quoted by Chevalier (1700), ambergris was a substance so tenuous as to be the dried foam of the sea, or, according to Cardan (in Crosse, 1863) the dried foam of seals. To some it was the excrement of a bird which was called Anacangrispasqui living on sweet-smelling herbs in the Maldives (Clusius, 1605, p. 148), or was called Aschibobuch and lived in Madagascar (Klobius, 1667).

\footnotetext{
${ }^{1}$ Apartado 40. Pisco. Perú. E-mail: robertclarke007@hotmail.com.

${ }^{2}$ R. Clarke et al (1988, p. 54) have explained in a footnote why I prefer Physeter catodon to P. macrocephalus as the specific name for the sperm whale.
} 
FRAGMEN AMBR. GRIS LIBRAR. 182. HUC ALLAT. 1694.

Piecs d'Ambre gris du poids de 182. livres, apportée en cette Ville l'an 1604.

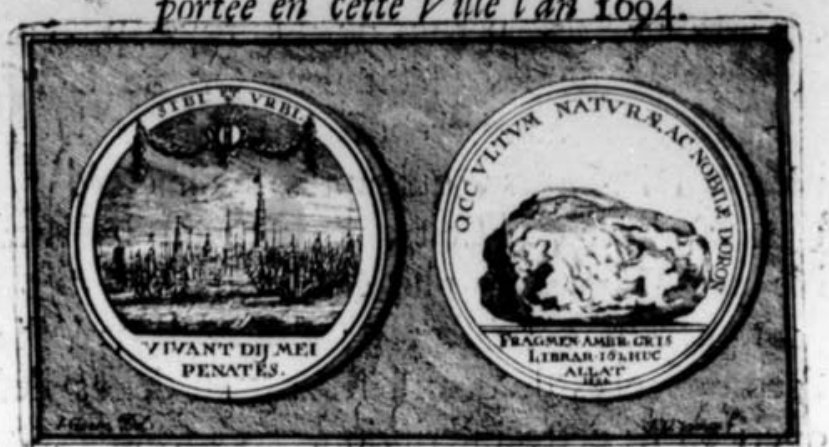

Sur le Revers on voit en perfpective la Ville d'Amfterdam, \& fon Port, couvert de deux

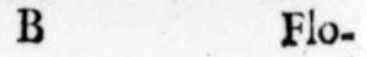

Figure 1. Medal struck in 1694 commemorating a boulder of ambergris weighing 83 $\mathrm{kg}$, presented by the King of Tidor in the Mollucas to the Dutch East India Company.

Doubtless the squid beaks found in ambergris prompted this idea. Crocodiles were noted by Rochefort (1658, p. 221) as a possible source of ambergris, a belief which must have arisen from knowledge or rumours of the 'lizard musk' which is still collected in Brazil and is a secretion from the paired hedonic glands found in the throat and cloaca of all the Crocodilia (Gadow, 1901, p. 443; Parry 1925, vol. 1, p. 479). Pomet held that ambergris was a waxy honeycomb which, melting from the rocks into the ocean, was perfected by the sun and the sea (1694, Part II, Ch. xxvi, p. 57). For Garcie du Jardin, quoted by Chevalier (1700), ambergris was a rare and odorous earth because it was veined and marbled as earths sometimes are, and logically he believed that the oceans must hide not merely great boulders but whole islands of ambergris. There were several theories which postulated a vegetable origin. The ninth century Arab who first recorded ambergris said it was a mushroom or truffle which grew at the bottom of the sea, a view also considered by Matthioli (1558, Lib. I, p. 47) and maintained to the exclusion of all others by Josselyn (1672, p. 36). According to Chevalier (1700) the philosophers Avicenna and Serapion held that the fungus was not torn up from the sea-bed, but, like Pomet's honeycomb, fell from the rocks into the sea. Chevalier added that for others it was not a fungus but a perfumed fruit which, ripening in April or May, fell into the sea; or, according to Averroës, a sort of camphor called Aschap which grew in the channels of the sea and floated adrift. A theory of vegetable origin, published by Robert Boyle in 1673 from a document found in a captured Dutch East Indiaman, stated that ambergris was a gum exuded into the sea from the roots of certain trees growing near the coast.
The obvious confusion here with true amber or fossil gum had in fact arisen much earlier in connection with a theory of origin, possibly more fashionable than any mentioned so far, which maintained that ambergris was a bitumen erupted from fountains at the bottom of the sea, a notion also widely held in regard to true amber, called ambre jaune. This confusion bedevilled the history of ambergris far into the eighteenth century, as may be seen by comparison of adjacent entries for 'Amber' and 'Ambergris' in the 1765 edition of Samuel Johnson's Dictionary. The idea of ambergris as a bitumen, noticed by Matthioli in 1558 and preferred by Sir Richard Hawkins (1593, in Purchas 1625, vol. xvii, p. 85), Rochefort (1658) and Sibbaldus (1692), was argued by Chevalier with ingenious references to vulcanism and associated with theories that ambergris was an ooze from mountains or a condensation of viscous salt water in sea sands. The bitumen theory died hard, for even in 1833 the Edinburgh New Philosophical Journal noted under the heading 'Antediluvian Ambergris':

In the clay ironstone of our coal-formation near to Bathgate, Burntisland we have been long familiar with a pale, yellowish-white and wine-yellow, translucent, soft, inflammable mineral, to which no particular name had been given. It is now said to have the chemical characters of ambergris.'

There were other ancient theories which confused ambergris not with amber but with spermaceti. This confusion, according to Pouchet (1893a), existed when spermaceti was first recorded in the school of pharmacy at Salerno about 1100. Certainly for Albertus Magnus, who died in 1280, ambergris was spermaceti which was the sperm of the whale (edition 1519, Lib. xxiii, reverse of folio 196), an opinion followed by Olaus Magnus in 1555 (edition 1652, Lib. xxi, p.578) and not put right until Clusius (1605, p.148) explained that spermaceti came from the head of the sperm whale and was not to be confused with ambergris. But the confusion lingered for some still thought that ambergris was the sperm of 'fish' when the ninth edition of Francis Bacon's Sylva Sylvarum was published in 1670 (p. 177) whilst Pomet in $1694\left(2^{\text {nd }}\right.$ partie, Ch. xxvi, p.59) mentioned 'ambre blanc' where he seemed to have had spermaceti in mind.

The confusion with spermaceti draws attention to the early association of whales with ambergris. According to Haupt (1907) this is even implicit in the name itself for 'amber' comes from the Arabic 'anbar' which also means the sperm whale in Arabic. Certainly the association dates from the earliest reference to ambergris known to me, that of the ninth century Arab traveller. All those authors so far mentioned, who believed that the substance was not whale 
sperm but had some origin outside the whale, either admitted implicitly with the $13^{\text {th }}$ century Marco Polo (edition 1906, p. 389) that ambergris was sometimes found in whales, or they would doubtless have been prepared to admit as much. Their explanation was simply that whales found the stuff floating in the sea and swallowed it. For a contemporary commentator on the travels of the ninth century merchant, the whale concerned was called Tal (Kerr, 1811-24, vol. I, p. 92), whilst for Matthioli (1558, p. 47) and others it was a fish or whale called Azel, although by 1686 Sir Thomas Brown (edition 1880, p. 356) recognized the 'ambrofage' as the sperm whale.

It was not until the sperm whale fishery had been established in New England that Boylston (1724) showed that the sperm whale did not swallow ambergris but actually produced it. He was at first challenged by those who believed in an independent origin and in 1734 the distinguished Prussian chemist Caspar Neumann defended the bitumen theory at considerable length in the Philosophical Transactions.

Although Boylston established the sperm whale as the responsible agent, he thought, as did later Vogt (1884, p. 287), that the ambergris was associated with the genitals and bladder rather than with the gut. Nevertheless, among the diverse and conflicting notions of the time there was already current a theory that ambergris was the excrement of whales. Thus Clusius in 1605 had said that a certain Servat Marel, an ambergris merchant, maintained that the substance was a food residue in the stomach of the whale. Clusius thought this was the right whale, although a few years later, in 1611, the Muscovy Company's commission to Thomas Edge, when he sailed as a factor to the Greenland fishery, enjoined him to look out for 'Ambergrease ... being of shape and colour like unto Kowes dung' in the guts of a whale called Trumpa which was certainly the sperm whale (Purchas, edition 1905-7, xiv, p. 32). Moreover Kaempfer, who himself believed that ambergris was a bitumen, reported in 1727 (p. 112; appendix p. 49) that the Japanese alone among civilized nations had no regard for ambergris which they called Kusurano fu or Kunsuranofuu, meaning whale's dung. It was not, however, until 1783 that Schwediawer pressed in a clear and convincing way the argument that ambergris is a faecal product of the sperm whale, and he should be considered the proper author of this view of ambergris as a coprolith.

\section{Modern theories of origin}

Schwediawer's ideas were widely held in the nineteenth century (Cuvier, 1836; Beale, 1839; Lacépède, 1841; Olmsted, 1841; Crosse, 1863; Southwell, 1881) but the few authors in the twentieth century who have entertained or developed them have received little attention. Suzuki (1925) believed, as I do, that ambergris arises from transformations of substances contained in the normal faeces, and he analyzed some sperm whale faeces although with inconclusive results. Gattefossé
(1920) and Parry (1937) held that the odorous elements in ambergris, and the characteristic constituent ambreine, are already present in the squid on which the sperm whale feeds, and that these substances normally pass undigested through the gut unless the whale is suffering from a microbial intestinal disease which causes the substances to be retained as a faecal concretion which becomes ambergris. Hasslauer (1921, 1947) proposed what may be called the faecal-biliary theory, combining Gattefossé's idea with the theory that ambergris is a biliary concretion.

The biliary theory, widely held since the beginning of the twentieth century (Beddard, 1900; Jenkins, 1932; Encyclopaedia Britannica, 1953) was first put forward as early as 1820 by Pelletier and Caventon who thought that the ambreine they had isolated from ambergris was very similar to cholesterol, suggesting that ambergris was a biliary matter similar to that in gallstones, although they were careful not to identify ambergris with gallstones. Also in 1820 Vogel examined a coprolith voided by a sick man, and, believing it to be of biliary origin, offered his findings in support of Pelletier and Caventon's (1820) views on ambergris. Although Riban (1912) contradicted the view that cholesterol and ambergris are closely allied, it is now generally agreed, from the evidence of certain transformations, that some relationship does exist between the triterpenes (in which series ambreine is a tricyclic alcohol) and the sterols (Simonsen \& Ross, 1957). Pouchet (1892, 1893a, b) inclined to the view that ambergris was a biliary concretion, although he insisted on its intestinal origin. Pouchet \& Beauregard (1892) both regarded ambergris as a true bezoar of the sperm whale, as did also Beddard $(1900,1909)$, although Beauregard (1898) did not commit himself to the biliary theory, claiming only that the ambergris concretion owed its origin to microbial activity, an idea presumably taken up later by Gattefossé (1920) as already mentioned.

The reasonable suggestion that ambergris might be formed like the aegagropile or 'hair-ball' in the stomach of an ox was made by Carter (1873), 'the horny beaks of cuttlefish forming the ingesta', but it will be seen (p. 8) that ambergris is formed not in the stomach but in the rectum of the whale.

Zell's suggestion (1917) that ambergris is a sexual secretion or hedonic scent, comparable to castoreum, may be dismissed because ambergris occurs rarely and not regularly in sperm whales (p.7), because the site of the formation is the gut and not the urinogenital system, and because whales have little or no olfactory sense (Fraser, 1952) whereby the scent could be detected by the opposite sex. Zell's idea arose from associating ambergris with three other animal substances used in perfumery; these are civet, musk and castoreum from, respectively, the civet cats (Viverridae), the musk deer (Moschus moschiferus) and the beavers (Castoridae), and all these secretions, as Beauregard (1901) has shown, are produced by glands of preputial origin. 
Peele (1932), whaling in Japanese waters, said it was well known that ambergris arose from irritation caused by the lodging in the small intestine of a small devil fish. Such infected whales had large sores over the body and had a foul smell. Tomilin (1967) appeared sympathetic to this idea.

Another theory in modern times is that ambergris is a pathological substance arising from irritation of the lining of the gut by the horny beaks of squid passing undigested with the faeces. Originating late in the nineteenth century, this has been the view of several chemists (Stirling, 1934; Lederer, 1949, 1953; Tixier, 1953) whilst Thomas (1955) was undecided between this and Beauregard's theory of a microbial origin.

Apart from the opinions of the uncommitted, such as Janistyn $(1947,1956)$ for whom ambergris is an 'intestinal metabolic product' the theories of biliary origin and origin by irritation were those generally accepted to the neglect of the faecal theory repudiated, as earlier observed, by Bovill (1954). However, in the second half of the twentieth century the faecal theory gained ground until Lambertsen \& Kohn (1987) could say 'The probability that ambergris in the sperm whale forms as a pathological concretion of faecal material is generally accepted.'

\section{Chemical composition of ambergris}

Since ambergris is unsurpassed in perfumes as a stabilizer and fixative, its chemical composition has attracted much attentiom. In the middle years of the twentieth century teams of perfumery chemists, led by Ruzicka in Zurich, Lederer in Paris, Stoll in Geneva and Thomas in Hamburg, not only elucidated the composition of ambergris but also managed to synthesise several of the constituents, including ambreine and some of the volatile odorous compounds which contribute to the ambergris scent. Suitable blends of these synthetics have been marketed under trade names like Grisambrol, Ambropur and Ambrofix. However, published accounts of the synthesis of ambreine and other constituents seem to give no clue to the biochemistry of the formation of natural ambergris.

Lederer $(1949,1953)$ gave the following composition for ambergris of good quality.

\begin{tabular}{||l|c||}
\hline BIOCHEMICAL & PERCENT COMPOSITION \\
\hline Ether-insoluble fraction & $10-16 \%$ \\
\hline Pristane, $\mathrm{C}_{18} \mathrm{H}_{38}$ & $2-4 \%$ \\
\hline Ambreine $\mathrm{C}_{10} \mathrm{H}_{52} \mathrm{O}$ & $25-45 \%$ \\
\hline epi-Coprosterol, free and esterified & $30-40 \%$ \\
\hline Coprosterol & $1-5 \%$ \\
\hline Cholesterol & $0-1 \%$ \\
\hline $\begin{array}{l}\text { Ketones } \\
\text { (of which more than 50\% } \\
\text { are of coprostane-3-one) }\end{array}$ & $6-8 \%$ \\
\hline Free acids & $5 \%$ \\
\hline Esterified acids & $5-8 \%$ \\
\hline
\end{tabular}

(Of course the proportions of the ingredients vary somewhat, to be expected from analyses of a natural product from samples of different provenance).

Lederer (1949) noted that the liquid paraffin pristane was already known from the liver oil of the basking shark (Cetorhinus maximus). Ambreine is a tricyclic triterpene alcohol. Simonsen \& Ross (1957, p. 24 ff.) have reviewed the elucidation of its complex structure. Isolated by Pelletier \& Caventon (1820), ambreine was long considered to be the sole active principal, that is, 'pure ambergris' rid of the dross of nature. Coprosterol, as its name implies, is well known to occur in animal faeces, and Lederer noted that epi-coprosterol has been recorded from the faeces of dogs. Coprosterol and epi-coprosterol are presumably formed from cholesterol although there was only a tiny proportion $(0-1 \%)$ of cholesterol in Lederer's samples of ambergris.

\section{Odour of ambergris}

Ambergris taken fresh from the whale's rectum has a faecal smell; I have recorded it as a pungent reek like that of blood-meal sold as fertilizer. But when ambergris has dried out and matured, samples of good quality acquire a delicious and subtle fragance, and in modern perfumery ambergris is still esteemed for this scent as well as for its fixative powers. Unique, illusive of precise description, the odour of ambergris has been said to suggest fine tobacco, the wood in old churches, sandalwood, the smell of the tide, fresh earth and fresh seaweed in the sun. I myself am reminded of brazil nuts. All admit the presence of a slight animal tang, what Hasslauer (1947) called an 'indolent note'. Hasslauer distinguished four, and Janistyn (1956) five notes, in the odour of fine ambergris.

Pouchet (1892) suggested that the odour of ambergris is actually the special smell of the sperm whale rarefied through the vehicle of ambreine. All those who have examined fresh sperm whales, or their flesh or viscera, will know this characteristic sperm whale smell which is unlike that of any whalebone whales, and it certainly recalls the smell of ambergris. Authorities are now agreed that ambreine itself is odourless, although it would seem largely responsible for the fixative power of ambergris (Firmenich \& Cie 1955). The volatile substances responsible for the odour must be formed in very minute quantities because ambergris, once it has dried out, loses scarcely any weight over the years. Guibourt (1876, IV, p. 122) found that a piece weighing 54.96 grams in 1832 showed no detectable loss in weight in 1836, and had lost only 0.39 gram by 1850 . Most of the volatile odorous substances, including gamma-dihydroionome and tricyclic oxides and ketones of ambreine, are formed by the continuous oxidation of ambreine (Collin-Asselineau 
et al, 1950). Lederer has suggested that this oxidation of ambreine is catalysed by the copper which Schmidt-Nielsen \& Flood (1936) had detected in ambergris and which is believed to come from the haemocyanin in the blood of squids which are the staple food of sperm whales. It has also been suggested that autoxidation is provoked by ambergris compounds of high molecular weight acting as oxygen donors (Ohloff, 1955), whilst Stoll (1954) thought that oxidation takes place when ambergris is floating in the sea, buffeted by wind and wave, although this is certainly unnecessary because ambergris taken straight from the whale also acquires the true odeur ambrée in time.

\section{Ambergris in whales other than the sperm whale}

Although the sperm whale is nowadays generally believed to be the only animal which produces ambergris, there is reason to believe that it also occurs in the pygmy sperm whale (Kogia breviceps). A German encyclopaedist, writing about 1630 , said that ambergris could be found in the stomach of a small species of whale hunted in Japan (Chevalier, 1700); and the 'cetus minor ambrophagus' of Cleyerus (1689) was also a small whale from Japan. Kaempfer (1727, p. 133) mentioned that ambergris could be found in the gut of a whale called Mako, which corresponds with Makko kouzira or Ouki kouzira reported to Pouchet (1893b) as the pygmy sperm whale and, moreover, correctly reported because Yamada (1954, p. 54) has shown that Uki-kujira was definitely the name for the pygmy sperm whale in nineteenth century Japan. Ratcliffe (1942) reported an obstruction in the gut of a pygmy sperm whale which could have been ambergris. The sperm whale and the pygmy sperm whale, which both feed on squids, are so closely allied anatomically that it is reasonable to expect that the pygmy sperm whale, and perhaps also the dwarf sperm whale Kogia sima, can produce ambergris.

According to Jenkins (1932, p. 115) ambergris also occurs in the northern bottlenose whale (Hyperoodon ampullatus), but I can find no support for this statement.

Opinions that ambergris might come from whalebone whales, favoured by Clusius $(1605$, p. 148$)$ and even as late as 1876 by Guibourt (vol. IV, p. 121), or might come from either toothed or whalebone whales (Sibbaldus, 1692, p. 98) doubtless arose from insufficient knowledge or mistaken premises. However, it is interesting to note that a whalebone whale can produce faecal concretions comparable to ambergris. A solitary instance has been recorded: the late Dr F.D. Ommaney described, in an unpublished report to the Discovery Committee in 1930, how the rectum of a male blue whale (Balaenoptera musculus) examined at Durban in that year contained some thirty concretions having diameters between 5 and $25 \mathrm{~cm}$. Analysis by the Government Laboratory in London showed that they were composed of faecal matter. Ommaney (1938, p. 97) later mentioned that he broke open one of the lumps and found inside a bunch of whalebone bristles which, had the material been ambergris, he believed could have set up an irritation in the intestinal wall just as squid beaks are supposed, according to one current theory already described, to provoke ambergris formation by irritation of the walls of the rectum of the sperm whale.

After this introduction there follows my argument how ambergris is formed as a coprolith.

\section{Material}

In the Antarctic, in the Azores Islands and in Edinburgh and London I have examined six finds of ambergris of known provenance. They are listed below.

A boulder (Figure 2) weighing $155 \mathrm{~kg}$ which I found in a male sperm whale, no. SH4, 16.0m long, worked up on board the factory ship Southern Harvester in $55^{\circ} 59^{\prime} \mathrm{S}, 03^{\circ} 02^{\prime} \mathrm{E}$ on 21 November 1947 (R. Clarke, 1949).

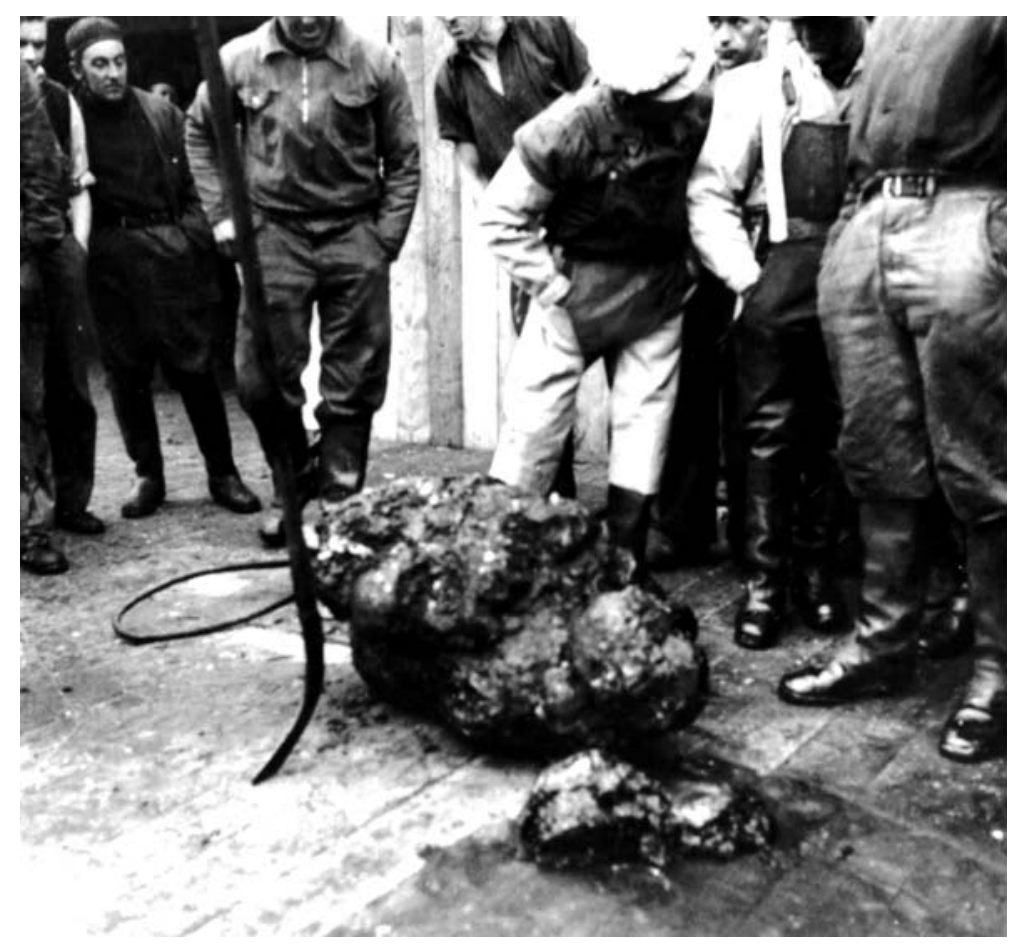

Figure 2. Boulder of ambergris weighing $155 \mathrm{~kg}$ taken from a male sperm whale

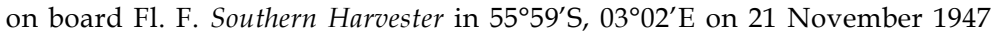
(Photo: Robert Clarke). 
A boulder (Figure 3) weighing $421 \mathrm{~kg}$ from a male sperm whale $14.9 \mathrm{~m}$ long, worked up on board the same factory ship in $58^{\circ} 23^{\prime} \mathrm{S}, 14^{\circ} 13^{\prime} \mathrm{W}$ on 21 December 1953 . I examined this find in May 1954 at the office of Messrs Chr. Salvesen \& Co, Edinburgh (R. Clarke, 1954a).

A lump weighing $19 \mathrm{~kg}$ from a male sperm whale worked up at the whaling station in Sâo Vincent, San Miguel, Azores on 27 June 1949 which I examined the same day (R. Clarke, 1954b, p. 347).

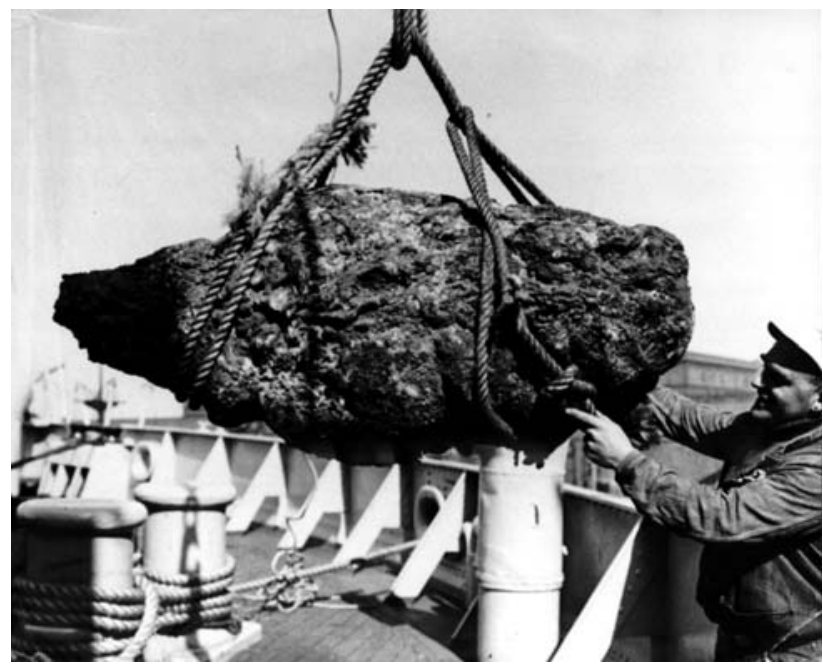

Figure 3. Boulder of ambergris weighing $421 \mathrm{~kg}$ taken from a male sperm whale on board Fl. F. Southern Harvester in $58^{\circ} 23^{\prime} \mathrm{S}, 14^{\circ} 13^{\prime} \mathrm{W}$ on 21 December 1953. (Photo: courtesy of Messrs Chr. Salvesen \& Co.)

A lump (Figure 4) weighing $4.1 \mathrm{~kg}$ from a male sperm whale worked up at the whaling station in Porto Pim, Horta, Fayal, Azores in June 1949 and examined on 12 July 1949.

In front of the lump there is a 'parcel' of three small lumps or 'rognons' weighing $0.06,0.09$ and $0.12 \mathrm{~kg}$ taken from a male sperm whale, F5, $15.1 \mathrm{~m}$ long at Porto Pim on 12 July 1949 and examined the same day (R. Clarke 1954b, p. 347).

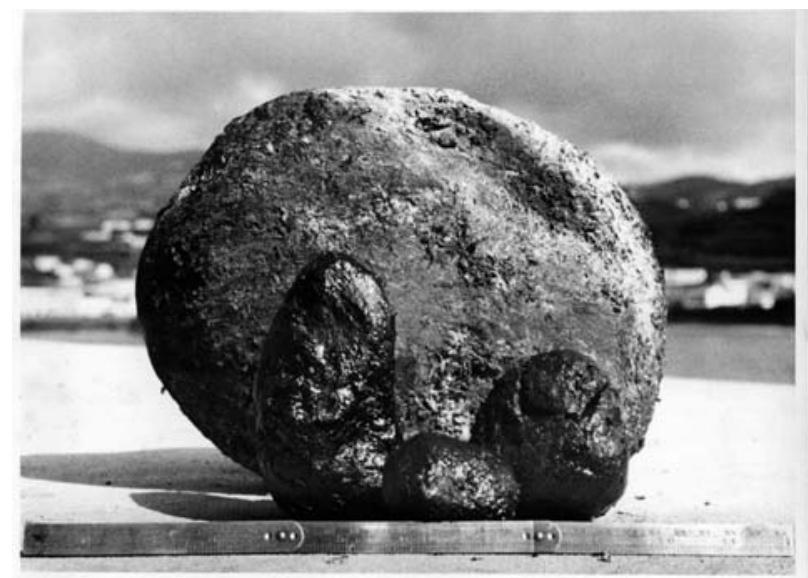

Figure 4. Lump of ambergris weighing $4.1 \mathrm{~kg}$ taken from a male sperm whale at the whaling station in Porto Pim, Fayal, Azores Islands in June 1949. In front of the lump there is a 'parcel' of three small pieces or 'rognons' of ambergris weighing $0.06,0.09$ and 0.12 kgs taken from a male sperm whale also at Porto Pim on 12 July 1949 (Photo: Robert Clarke).
A fragment of 'jetsam' ambergris, weighing $0.6 \mathrm{~kg}$, picked up on the beach at Mason Bay, Steward Island, New Zealand in February 1951 and presented by Dr. Brian M. Bary (Fig.8, p.11).

\section{Ambergris and the sperm whale}

\section{Provenance}

Ambergris may be found in sperm whales (where it is called 'body ambergris'), or floating on the sea (flotsam), or washed up on the shore (jetsam). Since sperm whales are cosmopolitan ambergris may be found in any ocean or upon any ocean shore; one may of course expect finds more frequent in seas, or on the shores of sea, where sperm whales are abundant, unless the shoreline be such as the coast of Peru where the oceanic current sets offshore.

\section{IN FEMALES AS WELL AS IN MALES}

It is commonly said that only the male sperm whale produces ambergris. But there is no doubt that it also occurs in the female. In 1791 the whaling captain Joshua Coffin, summoned before a Committee of the Privy Council in London, described his find of ambergris in a female sperm whale (Fawkener \& Lords of the Committee of Council, 1791). Beale (1839, p. 130) also reported this meeting. Earlier Schwediawer (1783) had explained that both females and males of the sperm whale could produce ambergris and later the Norsk Hvalfangst Tidende (Anon., 1929) mentioned Japanese reports of substantial finds of ambergris from female sperm whales. Murphy (1933) also reported ambergris from females. The idea that ambergris is confined to males still persists because when most whalers bother to search the sperm whale intestines they only search those of males, and also because the length restrictions of the International Whaling Commission protect all but the largest female sperm whales so that anyway few females are caught.

\section{Frequency of incidence}

There has been a good deal of speculation on the frequency of incidence of ambergris in sperm whales. Dudley (1725) said that one in three whales had ambergris, whereas the whaleman Captain Francis Post estimated 'perhaps one whale out of a thousand' (Maury, 1852, p. 244). Since Dudley's time the most fashionable estimate has been one in a hundred (Boylston, 1724; Johnson, 1765; Thomas, 1955). The Japanese are scrupulous in their search for ambergris and Kamimura (1953) said that in 1952 his company found ambergris ten times in a catch of 1800 sperm whales, say, one in 200. Mr H.S.J. Roe, of the British National Institute of Oceanography, examined 66 sperm whales in Iceland in 1967 and found ambergris in two of them, or three in a hundred (Personal information). The same incidence (3-4\%) 
was found in Soviet whaling in the Antarctic in 1962 (Ivashin, 1963).

The most realistic figure for the incidence of ambergris is to be found in the Azores islands in mid-North Atlantic. Here whaling for the sperm whale was conducted from open boats (R. Clarke, 1956) until Portugal joined the European Union in 1987. Portugal did not join the International Whaling Commission so that male and female sperm whales in the Azores catches were representative of the proportions in the sea. The routine search for ambergris was made only in male whales, except in the whaling station at Sâo Vincent on the island of San Miguel. Here, as I learned when I visited Sâo Vincent in June 1949, special attention was given to the search for ambergris in all whales caught, both males and females. Table 1 is therefore limited to figures from Sâo Vincent between 1934 and 1953 and shows that a catch of 1,933 sperm whales produced $1,115.55 \mathrm{~kg}$ of ambergris, or $0.58 \mathrm{~kg}$ for each sperm whale caught (which means little as an average figure) and an incident of ambergris of once in 102 whales. So I conclude that ambergris occurs in one out of every hundred sperm whales in the sea. It should not be excluded that significant geographic variation may exist in incidence rate, which may explain the apparently higher rate found in the Antarctic.

\section{Size range of ambergris finds}

In the parcel I examined in 1949 (Fig.4) the smallest of the three balls or 'rognons' weighed 6 grams. This piece, and the $421 \mathrm{~kg}$ boulder taken in 1953 by the Southern Harvester expedition (Fig. 3), which I examined in 1954, come near to limiting the size range. Although The Times ${ }^{3}$ of London on 15 December 1947 printed a report that the Brazilian steamer Araxa had chanced upon a mass of ten tons of ambergris at sea, it is not surprising that this 'ambergris' proved to be spermaceti (Raoul et al., 1952). The manifest of the bark Splendid of Dunedin, New Zealand showed $983 \mathrm{lb}(447 \mathrm{~kg})$ of ambergris in 1883 (Verrill, 1916, p. 21), but this was a production figure at the end of a long whaling voyage and so may have included ambergris from more than one whale. The largest find so far recorded was made off the Australian coast on Christmas Eve 1913 on board the factory ship Polynesia of the Antarctic Whaling Co. The boulder was in one piece and weighed $455 \mathrm{~kg}$. It was sold in London on 12 April 1914 for $£ 23,000$ sterling (Anon., 1914, p. 226; Dakin 1933, p. 189; Tønnessen 1962, p. 477; 1967, vol. 2, p. 484). A boulder of $982 \mathrm{lb}(446 \mathrm{~kg})$, which once belonged to the Dutch East India Company, was recorded by Van Beneden and Gervais (1880, p. 304). They cautiously suggested that this find might be several pieces stuck together, but there is no need to discount the record on present knowledge. The third largest haul was a boulder of $928 \mathrm{lb}(422 \mathrm{~kg}$ ) recovered in San Miguel, Azores in 1944 (Table 1) ${ }^{4}$. The boulder weighing $421 \mathrm{~kg}$ found on board Fl. F. Southern Harvester in 1953 (Fig. 3) is the fourth largest find.

Table 1. Production of ambergris at Sâo Vincent, San Miguel in the Azores between 1934 and $1953 .{ }^{*}$ From 3 whales. Production in all other years is understood to come from single whales.

\begin{tabular}{cccccc}
\hline \hline YEAR & $\begin{array}{c}\text { CATCH OF } \\
\text { SPERM WHALES }\end{array}$ & $\begin{array}{c}\text { AMBERGRIS } \\
\text { KILOS }\end{array}$ & YEAR & $\begin{array}{c}\text { CATCH OF } \\
\text { SPERM WHALES }\end{array}$ & $\begin{array}{c}\text { AMBERGRIS } \\
\text { KILOS }\end{array}$ \\
\hline \hline 1934 & 54 & & 1944 & 152 & 422.0 \\
1935 & 58 & $50.25^{*}$ & 1945 & 102 & 11.0 \\
\hline 1936 & 85 & 14.0 & 1946 & 117 & 0.9 \\
1937 & 102 & 15.0 & 1947 & 146 & 61.0 \\
1938 & 66 & & 1948 & 121 & 4.0 \\
1939 & 107 & 81.0 & 1949 & 87 & 19.0 \\
\hline 1940 & 65 & 3.0 & 1950 & 117 & 80.4 \\
1941 & 39 & 8.0 & 1951 & 103 & 78.0 \\
1942 & 61 & 53.0 & 1952 & 125 & 171.0 \\
1943 & 89 & 44.0 & 1953 & 137 & \\
\hline \hline & & & $1934-1953$ & 1,933 & 1155.55 \\
\hline
\end{tabular}

\footnotetext{
3 The Times, 15 December 1947. Rich Haul of Ambergris (see Rauol, Iachan \& Gottlieb, 1952).

${ }^{4}$ I have suggested (R. Clarke $1954 \mathrm{a}$ and $\mathrm{b}$ ) that this record might refer to production from more than one whale, but apparently only one whale was involved.
} 


\section{Condition of the whale}

Because a pathological origin has so often been attributed to ambergris, it is not surprising that whales bearing ambergris are commonly supposed to be sick and lean (Beddard, 1900). Almost every modern account of ambergris states this as a fact. Now I know only three instances where an objective report has been made on the condition of a whale with ambergris. The first was in 1947 when I found the boulder weighing $155 \mathrm{~kg}$ on board Fl. F. Southern Harvester (Fig. 2); the second was in the Azores in 1949 when I examined the small parcel of ambergris (Fig. 4); and the third was the report of the whale fishery inspector on board Fl. F. Southern Harvester when the boulder of ambergris weighing $421 \mathrm{~kg}$ was found in 1953 (Fig. 3). All these three whales were in good condition, had thick blubber and their stomachs contained food. I am confident that an ambergris concretion neither causes nor betrays disease in the sperm whale.

\section{Position of concretion in the whale}

There have been several opinions about the place where ambergris is formed in the sperm whale. Boylston (1724) said it was contained in a special bag or cyst, and Dudley (1725) and later Vogt (1884) and Zell (1917) confused this 'ambergris bag' with the urinary bladder. Stirling (1934) said that large lumps of ambergris were always found in the stomach. However, since the eighteenth century whalemen have known that ambergris is found in the rectum and have searched it with a pole or whaling spade (Colnett, 1798). But even Pouchet (1893), who did excellent work on ambergris, thought that the concretion must partially encyst in a lateral cul-de-sac of the lower rectum.

Five of the six finds whose circumstances I know (p. 17) were all in the rectum within a short distance of the anus, the sixth being jetsam. But the ambergris was not encysted but lay free in the rectum. The $155 \mathrm{~kg}$ boulder (Fig. 2) formed a great swelling in the gut. This mass was $0.65 \mathrm{~m}$ in greatest diameter. The larger $421 \mathrm{~kg}$ boulder (Fig. 3) was $0.75 \mathrm{~m}$ in greatest diameter and $1.63 \mathrm{~m}$ long. Both lay free in the rectum which was therefore greatly distended beyond its normal $15-18 \mathrm{~cm}$ of collapsed diameter.

When I cut out the $155 \mathrm{~kg}$ boulder I examined the walls of the rectum where the ambergris lay. The rectal mucosa showed no signs of haemorrhage, laceration or ulceration. I think this disposes of the theory that ambergris results from irritation of the walls of the gut by squid beaks (p.4). But after the ambergris boulder had been removed I did notice that the walls of the severed rectum, no longer under tension, seemed a little thicker in this region and the cut surface was congested, suggesting an increased blood supply and a low, subclinical level of inflammation. I return to this point later.

\section{The structure of ambergris}

\section{Shape of a large concretion}

The shape is significant of a large find of ambergris recovered from the rectum. The smaller finds, including the so-called 'rognons', occurring in groups or 'parcels', are more or less egg-shaped. Here I consider the large hauls, of which six have either been illustrated or I have seen myself. These are the king of Tidor's $83 \mathrm{~kg}$ mass (Fig. 1), one of $80 \mathrm{~kg}$ figured by Ruud (1937), a find of $18 \mathrm{~kg}$ made at Saldhana Bay in 1946 or 1947 of which photographs have been sent to me privately, the haul of $19 \mathrm{~kg}$ which I saw in Sâo Vincent, the Azores in 1949, the $155 \mathrm{~kg}$ boulder I found on board Fl. F. Southern Harvester in 1947 (Fig. 2), and the $421 \mathrm{~kg}$ boulder found on the same ship in 1953 and which I later examined (Fig. 3). All these masses are thicker at one end than at the other. The thick end has a depression, a kind of concavity, except the thick end of the largest haul, which is flat. The thinner end of each mass may taper, or be like a thick bobbin stuck out from the main mass, and its face is somewhat rounded or convex (Fig. 3). The orientation in the gut of these finds is known only regarding the two hauls from the Southern Harvester. Each of these, the $155 \mathrm{~kg}$ boulder and the $421 \mathrm{~kg}$ one, lay with the smaller end pointing towards the anus and the larger end pointing towards the stomach. This general shape, a broad end with concavity opposite to a tapering one, is what we might expect an obstructing mass to assume in the rectum. The liquid faeces strike the mass, scouring out a depression or saucer there as they are deflected to pass between the mass and the walls of the rectum, and flowing onwards to streamline in a rough taper the end of the mass pointing towards the anus. It is the broad end which is the most saturated by the faecal fluid, receiving the full force of the wash of faeces under peristaltic pressure.

\section{Surface of the concretion}

The smaller lumps of fresh ambergris I have examined have been black or blackish-brown on the surface, and somewhat plastic like very stiff putty. The two great hauls each had a black surface, fairly hard to the touch and massively nodular, the nodules themselves having a rather smooth surface. The presence of the horny beaks of squid in ambergris is well known; in the seventeenth century they were thought to be the beaks of birds (Pomet, 1694, $2^{\text {nd }}$ part, p. 57). These squid beaks, mostly more or less broken, were plastered over the surface, whilst broken fragments were easily recognized in the outer layers of the concretion (Fig. 5). They were not plentiful (Janistyn, 1947 gave $3-12 \%$ squid beaks) and they were all quite small, not more than 2-4 cm long. Beside squid beaks the surface of the $421 \mathrm{~kg}$ boulder was plastered with 
pieces of membranous stuff, squid pens or cuticles of parasitic nematode worms. Lumps of ambergris from the gut of the sperm whale, and not cast on shore or found floating at sea, have only been described on few occasions and these descriptions all mention crystals embedded in the surface of the finds. They were particularly abundant in the flattened face of the $421 \mathrm{~kg}$ boulder where they glinted in substantial clusters (Fig. 5). It was here that the boulder would have received the greatest impact of the faecal fluid. Mr Desmond King, chief chemist of the Southern Harvester, told me that the crystals were not apparent when the ambergris was found but they cropped out when the wet surface began to dry. They have been analysed and are crystals of magnesium ammonium phosphate. Carter and Elsey (1954) examined a boulder of ambergris from a sperm whale caught off British Columbia and found that the crystals on the surface were also magnesium ammonium phosphate. But Pouchet in 1893 had already noted that the liquid faeces of whalebone whales contained crystals of magnesium ammonium phosphate. Therefore Pouchet had asked whether, in animals with a 'combustion puissante' (by which I understand animals deriving much of their energy from the oxidation of proteins) the intestine might be one of the highways for eliminating the waste products of that combustion. We know that the large intestine of mammals is important in the excretion of magnesium and phosphate, but probably Pouchet had in mind the excretion of nitrogenous waste as ammonium. Now squids are extremely rich in protein and have comparatively little fat or carbohydrate (Lee, 1994). This being so, the squid food of the sperm whale constitutes a protein diet. Then the presence of these crystals in ambergris shows that the concretion has been saturated in a faecal fluid containing the waste products of a protein metabolism, excreted by the large intestine as ammonium and phosphate.

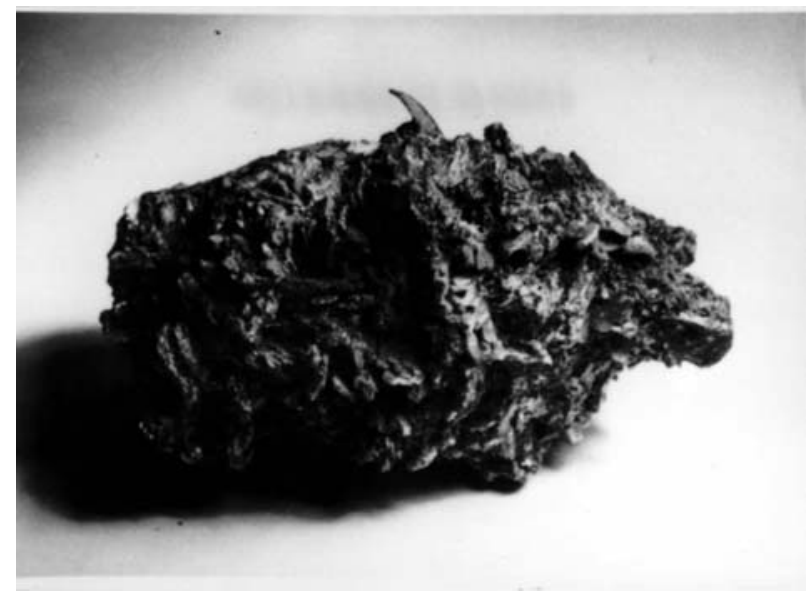

Figure 5. Mass of crystals (of magnesium ammonium phosphate) with a protruding squid beak from the surface of the $421 \mathrm{~kg}$ boulder of ambergris (Figure. 3). (Photo: courtesy of the British National Institute of Oceanography).

\section{Gross structure}

When a large haul such as either of the Southern Harvester boulders (Figs 2 and 3) is broken transversally, the fracture shows a series of concentric layers surrounding a central core, several centimetres across which appears structureless, that is, it is not layered. The outer layers of the mass are brownish-black changing to grayishbrown internally; they comprise a zone between 3 and $10 \mathrm{~cm}$ thick. Between this outer part and the core, gray in colour, there is a well-stratified zone, around $10 \mathrm{~cm}$ thick, of yellow and yellowish-gray ambergris (Fig. 6). The black ambergris of the outer layers, which is very poor quality to the merchant and perfumer, is poor in ambreine and other ether-soluble constituents, but has a high mineral content: the black outer part of the $155 \mathrm{~kg}$ boulder (Fig. 2) contained $57 \%$ of ash rich in phosphorus, magnesium and calcium oxides. This high mineral content and its nature are readily understandable considering the saturation of the outer layers with faecal fluid containing salts excreted from the intestine.

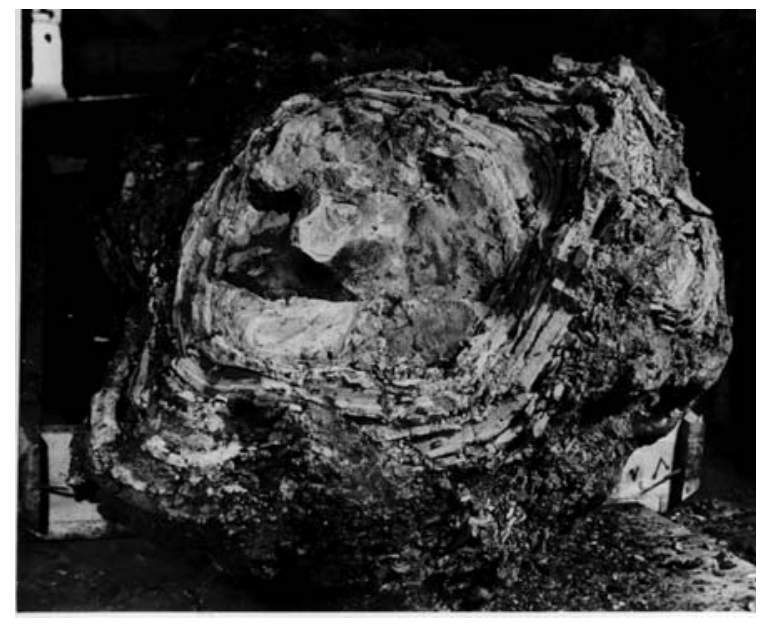

Figure 6. Cross section through the greatest diameter of the 421 $\mathrm{kg}$ boulder of ambergris (Figure 3). (Photo: courtesy of Messrs Chr. Salvesen \& Co.).

\section{Moisture content and specific gravity}

There are differences, which seem to me significant, in moisture content and specific gravity between the blackish outer part and the inner part comprising the yellow strata and the gray core.

On board the Southern Harvester in 1947 Mr Desmond King and I determined the specific gravity of fresh samples from the outer and inner parts of the $155 \mathrm{~kg}$ boulder (Fig. 2) and determined these again after the samples had dried in a dessicator for several days. The results gave also the moisture contents: the sample from the outer part contained $21.51 \%$ of water and that from the inner part contained only $12.73 \%$. No doubt there is a regular moisture gradient decreasing across an ambergris concretion, from, wet surface to dry core. 
These are the specific gravities determined before and after drying:

\begin{tabular}{||l|c|c||}
\hline & OUTER PART & INNER PART \\
\hline Fresh from the whale & 1.65 & 1.01 \\
\hline After 7 days drying & 1.06 & 0.87 \\
\hline
\end{tabular}

No doubt the specific gravity of ambergris depends largely on the water content. Now relative quantities represented in the $155 \mathrm{~kg}$ boulder by the damp, heavy outer part and the light, dry inner part, respectively, were such that the boulder would certainly have sunk in sea water where the whale had been killed. The specific gravity of this water was 1.026. But ambergris is sometimes found floating in the sea, and moreover such flotsam ambergris is always of fine quality without black material. What happens is that, when a large mass of ambergris is released from the whale, probably by breaking up of the carcase after death, the mass sinks at first, but the heavy black outer layers (which easily detach) are soon abraded away, when the light inner part rises to the surface and floats there. This inner part, of good quality ambergris, lies awash maybe for years, being leached out by the sea and bleached by the sea and the sun, becoming delicately odorous and of a colour sometimes plaster-white, before it strands upon some beach or is chanced upon by a fortunate voyager.

\section{The lamella structure}

The lamella structure of the inner yellow and gray parts of ambergris are now considered. The core of a large mass, and small finds of ambergris not more than, say 15 or $18 \mathrm{cms}$ across, do not in my experience show stratification. But all masses of any size are stratified around the core (Fig. 6). This has been known for centuries. Chevalier's lithographs of 1700 show the strata or lamellae clearly. Ambergris then is constructed as a series of concentric shells around a core. The lamellae of the inner part, those which show yellow or grayish in transverse fracture, often show crevices or cracks at their junctions, and the interface can be seen to be covered with a thin deposit of black pigment. Recognisable fragments of squid beaks can sometimes be seen at lamella junctions in the strata nearer to the black outer portion.

So it is clear that ambergris begins as a simple concretion but thereafter is discontinuously accumulated, the interfaces of successive strata each representing a former surface of the concretion. Pouchet drew attention to this in 1893. The black pigment at each interface (Fig.9) he attributed to deposition of melanin on a former surface by glands in the lower part of the rectum, which in this region has strongly pigmented walls, like waxed shoe leather.

\section{'Végétations cryptogamiques'}

Within the fissures between the strata and under the minute ledges in the fractured surface of ambergris the microscope reveals growing clumps of mould (Fig. 7). These moulds are the 'végétations cryptogamiques' of Pouchet and Beauregard (1892) and Beauregard (1898). It is not suggested that these moulds exist in the rectum of the whale. A fresh find of ambergris, a damp lump of organic substance, is a perfect substrate for fungal spores. A fresh lump kept in any shady place is soon covered with a white efflorescence which Guibourt (1876) mistook for ambreine. But even in dry fragments of ambergris these microscopic clumps of mould remain, even after at least ten years, as may be seen in Figure 7, a photomicrograph taken in 1957 of a fragment from my find of 1947 (Fig. 2).

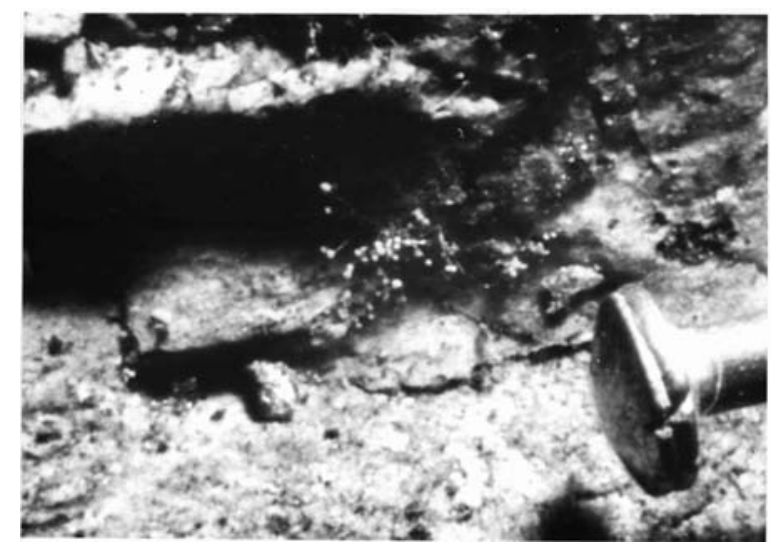

Figure 7. 'Vegetations cryptogamiques' in a photomicrograph of a crevice between strata of yellow ambergris from the $155 \mathrm{~kg}$ boulder (Figure 2). The head of a pin is shown for comparison (Photo: courtesy of the British National Institute of Oceanography).

Beauregard and Pouchet thought that the 'végétations cryptogamiques' might be concerned in the dissociation of ambreine. It is perhaps more likely that these moulds may play a part in destroying the unchanged faecal matter which invests fresh ambergris and gives to a new find its pungent faecal reek. This smell gradually fades as the ambergris matures over the months and years until it acquires the fine, delicate note esteemed by perfumers. Beauregard (1898) thought that the agent responsible for destroying the faecal matter was a new bacterium Spirillum recti physeteris, which he isolated from a piece of ambergris which was at least four years out of the whale.

\section{The ambergris material}

This forms the substance of the strata or lamellae. One may discern two structural elements in the ambergris substance. These are fragments of chitin, some so small as to be only a few microns in size, and whitish spherical aggregates of minute crystals (Fig 8). Strata near the black outer part of a mass have a speckled appearance due to finely divided fragments of chitin. Cole in 1922 
said that the presence of chitin fragments under the microscope was diagnostic of ambergris. Even the core, and the strata adjacent to it, are thickly sown with chitin particles. I have boiled fragments of the apparently homogeneous core with caustic soda, and, after separating and centrifuging, have obtained a residue which, mounted in canada balsam, shows minute fragments of laminated structure which I think must be chitin. This chitin must come from squid beaks and squid pens, or from the cuticles and eggshells of dead nematode worms or from all of these. In any case we may say that chitin material is distributed all through an ambergris find, from small entire squid beaks, squid pens and nematode cuticles embedded in the surface, through broken pieces of beaks or pens or nematode cuticles in the superficial layers, to increasingly tiny fragments inwards to the core. Chitin is probably included in the interspace of black pigment present between strata of yellow ambergris (Fig. 9). Pouchet (1892) attributed this black pigment to deposition of melanin on a former surface by glands in the lower part of the rectum.

The crystalline spherites, which occur with increasing density from surface to core of an ambergris find, were first observed by Pouchet (1892) who thought they were ambreine, as indeed they may be (Figs. 8 and 9).

The Government Chemist in London kindly undertook analyses of the $155 \mathrm{~kg}$ boulder I found in 1947 . One referred to three samples taken between the outer layers and the core of the nodule.

\begin{tabular}{|l|c|c|c|c|c||}
\hline & & & $\begin{array}{c}\text { OUTER } \\
\text { LAYERS }\end{array}$ & $\begin{array}{c}\text { YELLOW } \\
\text { INNER PART }\end{array}$ & CORE \\
\hline Sample & & & & & \\
\hline Ether extract & $\%$ & $10-11$ & $97-98$ & $95-96$ & \\
\hline Ambrein & $\%$ & 1.0 & 18.1 & 28.0 & \\
\hline Ash & & $\%$ & 57.4 & 5.0 & 1.7 \\
\hline
\end{tabular}

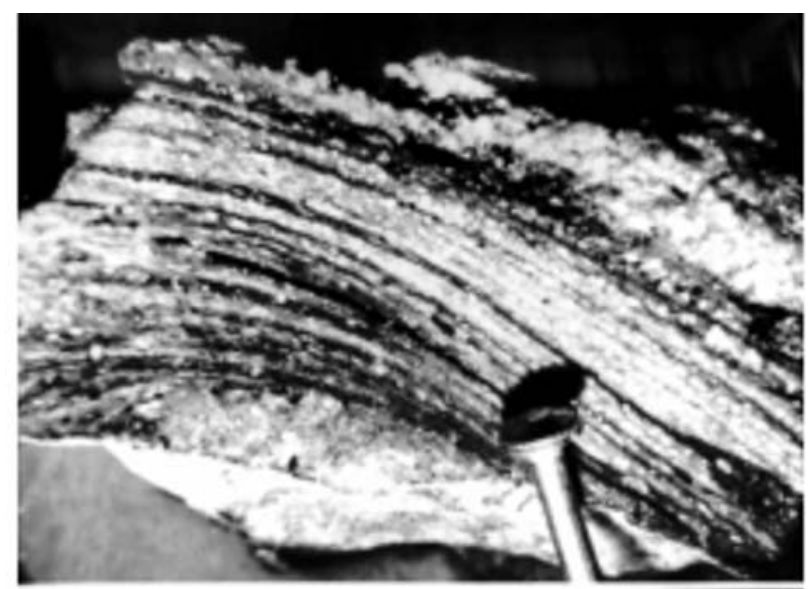

Figure 8. Spherites of ambergris-substance thickly distributed through the strata in a photomicrograph of the 'jetsam' ambergris from New Zealand. The head of a pin is shown. (Photo: courtesy of the British National Institute of Oceanography).

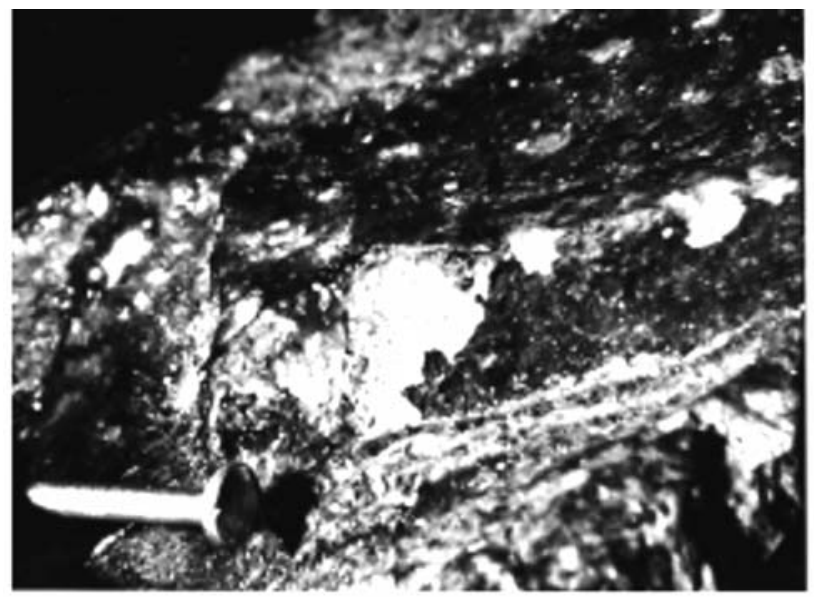

Figure 9. Photomicrograph of a fragment of yellow ambergris from the $155 \mathrm{~kg}$ boulder (Figure 2). The broken edge of a stratum extends away towards the right from the head of a pin inserted for comparison. Above this broken edge the surface of the succeeding stratum is exposed; it is covered with black pigment except for a patch on the left where the pigment layer has broken away to expose the pale ambergris-substance in which spherites can just be seen (Photo: courtesy of the British National Institute of Oceanography).

The gray core is richest in ambrein, the strata of the yellow inner part contain less, and the black outer part contains only $1 \%$ of ambrein. Conversely the mineral content, including phosphorus and magnesium, decreases towards the core. This distribution indicates a gradient of ambrein content increasing, as I believe steadily, from the periphery of the mass towards the core.

\section{Excretion of indigestible material by the sperm whale}

Schwediawer (1783) said 'We may therefore define Ambergris to be the praeternaturally hardened dung or faeces of the Physeter Macrocephalus, mixed with some indigestible relics of its food.' I agree with Schwediawer but first we must ask - what happens to these indigestible relics in the normal whale? Why do not all sperm whales, and not one in 100 , get a stoppage in the gut and produce ambergris?

Sperm whales have four stomachs and most of the food is found in the second and first stomachs (R. Clarke et al., 1988). Squids are the principal food of the sperm whale, and the parts undigested are the horny beaks and, to a lesser extent, the squid pens and even the eye-lenses. Quantities of beaks, sometimes very large quantities, are usually found in the stomachs. Betesheva and Akimushkin (1955) recorded as many as 28,000 beaks, representing 14,000 squids, in the stomach of a single whale. The bulk of indigestible material is swelled by numbers of the parasitic nematode worm Anisakis, and on one occasion a stomach has been estimated to contain about $45 \mathrm{~kg}$ of these worms. Many are dead but are recognizable for some time presumably because the chitinous and collagenous parts of the cuticle resist digestion. 
Yet, in spite of these great accumulations of indigestible material in stomachs, it is rare to find even one or two beaks in the intestine, and when we do find them they are always small, between 2 and $4 \mathrm{~cm}$ long. Furthermore, one sometimes examines whales whose stomachs contain very few beaks or worms. Clearly the indigestible material is vomited. M.R. Clarke et al. (1976) put the vomiting interval at about 10 days. R. Clarke et al. (1988) estimated that males vomit every 6.3 days after normal full meals and at about every 5 days after full meals at satiety; the corresponding estimates for females were 8.4 days and 7 days.

Thus the sperm whale's intestine and its musculature must be adapted to deal only with the transport of liquid faeces.

Now once in the Antarctic in 1948 on board Fl. F. Southern Harvester I examined a sperm whale whose cylindrical last stomach was entirely filled with a compacted mass of squid beaks, squid pens and nematode worms. The mass was $1.2 \mathrm{~m}$ in length and $0.4 \mathrm{~m}$ in diameter. This last stomach is normally empty except for a few small beaks, pens and nematode cuticles.

We have only to imagine an imperfect valve, a leaky sphincter between this last stomach and the intestine, when all conditions are set for a train of events which should result in ambergris.

\section{Ambergris a coprolith}

Suppose some quantity of tangled, indigestible material leaks into the intestine in this way. The wash of the fluid contents of the intestine carries the stuff down to the rectum. The stuff becomes saturated with faeces but it is not excreted at the anus because the sphincter muscle cannot adapt itself, relax sufficiently perhaps, to allow the expulsion of solid material. This mass, now clogged with faecal material, becomes an obstruction in the rectum and the liquid faeces are dammed against it. The whale now reacts to the stoppage in such a way that the flow of faeces can eventually be resumed. This reaction might be a local increase in the water-absorbing capacity of the rectum. It will be recalled that the walls of the rectum around the $155 \mathrm{~kg}$ boulder were congested and slightly thickened, suggesting increased physiological activity in this region (p.8). With absorption of water the faeces impregnating the mass become a cement binding the material together and smoothing the tangled periphery of the mass. Once it has become plastic the to-and-fro movements of peristalsis help to smooth and shape it. The total effect is to isolate the mass as a concretion. When the whale stools again the faeces can flow, as through an annulus, between the concretion and the walls of the rectum. But these faeces bring further detritus which again would dam the faecal flow, were it not that water is again absorbed so as to impaste and embed the newly arrived materials onto the surface of the concretion. By this intermittent process the concretion is built in layers or strata around the non- stratified core, the original obstructing mass. Such is the architecture of ambergris.

The concretion grows and grows, it may be for many years, but the faeces are able to pass and the whale remains healthy. However, there comes a time when the walls of the rectum become so distended that they rupture and the whale dies when the ambergris is released into the sea.

So the gut reacts to the threat of obstructing indigestible matter by building this matter into a concretion (which becomes ambergris) so that the flow of the liquid faeces is maintained, although at the expense of accretionary growth in size of the coprolith.

Response processes in the whale are constructional. The biochemical processes which transform the coprolith into ambergris are merely consequential upon its incubation over a long period in the peculiar environment of the rectum teeming with bacteria.

\section{Biochemistry of ambergris formation}

I hesitate to embark on biochemistry but here are some suggestions which may be pertinent to ambergris formation.

Bacteria must be the principal agents acting on the faecal cement, comprising water with dissolved mineral salts rich in ammonium and phosphate, undigested food, bile pigments, enzymes, dead bacteria and mucous. Bacteria must also be acting on the matrix of squid beaks and pens and nematode worm cuticles, which by clastic action they must break up into fragments which become mere particles in the core or oldest part where processes have continued longest. Bile additives must be a substantial ingredient of sperm whale faeces for the epicoprosterol component of ambergris is presumably formed from cholesterol, although of cholesterol itself there is scarcely more than a trace $(0-1 \%$, p. 4$)$. Bile pigments are presumably the source of the porphyrin found in ambergris (Susuki, 1925) and which cannot be derived, as Lederer $(1949,1953)$ suggested, from hemorrhage of the wall of the rectum.

Sammons et al. (1956) found that bacteria exist in human faeces which can synthesize fats from fat-free media. Then it may be that Beauregard's Spirillum recti physeteris and other bacteria are capable of even more ambitious syntheses in the whale's coprolith. One may object that syntheses involving fats could not proceed in the intestine because any fat, as soon as formed, would be decomposed by lipase, present in the faeces, into fatty acids and glycerol. However, heavy metals, like cupric, mercuric and ferric ions, are known to inhibit lipase. There is copper in ambergris and chromium also, since more than a trace of chromium has been found in squid beaks. Then we may suppose that any fats synthesized in the coprolith can be further elaborated.

On the synthesis of ambrein itself I can say nothing except for these general indications. It is not preformed 
in the squid food of the sperm whale. The idea that squid and ambergris are directly associated is quite old: Virey (1803) proposed that ambergris was an unctuous mass of decomposing squid. Bosc (1803) suggested that ambergris was formed from the indigestible ink of squids. Later Gattefossé (1920) claimed that the odorous components of ambergris, and their crystallisable matrix ambreine, pre-exist in those squids with a musky odour like Eledone moschata. However Lederer (1953) found no ambrein in the squid Moroteuthis ingens which is the staple diet of sperm whales in the Antarctic where sperm whales with ambergris are found. It seems that ambrein must be the result of a lengthy synthesis, considering that ambrein in an ambergris concretion increases from the periphery to the core.

To test the faecal origin of ambergris the Government Chemist in London began in 1957 an elaborate analysis of sperm whale faeces, but I have heard nothing of the results.

Crosse (1863) said that ambergris 'se prepare dans un singulier laboratoire, mais se n' est pas notre faute....'

\section{Acknowledgments}

I did most of the research for this paper when a member of the Discovery Investigations and later of the British National Institute of Oceanography.

I recall with pleasure the collaboration of the late Captain Konrad Granøe, his officers and men during the expedition of Fl.F. Southern Harvester in 1947-48. Messrs Christian Salvesen \& Co. of Leith, Scotland, owners of the vessel, kindly authorized facilities. I thank Mr Desmond King, chief chemist on board the Southern Harvester, for his help in examining the two boulders of ambergris, one at sea in 1947, and the other on shore at Edinburgh in 1953 when the whaling inspector Commander Percy Ashe, R.N. also helped. The Government Chemist in London analysed some ambergris samples. Mr H.S.J. Roe of the British National Institute of Oceanography kindly provided information on ambergris found in whales in Iceland in 1967. I recall with pleasure the cooperation of the open boat whalers of the Azores during my work in the islands in 1949. Dr Brian M. Bary kindly provided the fragment of jetsam ambergris (Fig. 8 ).

My best thanks go to Dr Koen Van Waerebeek, Peruvian Centre for Cetacean Research (CEPEC), Museo de Delfines, Pucusana for his critical and sympathetic review of the text. And I thank also Dr Alan Baker, Kerikeri, New Zealand for his kind review.

\section{References}

AnONYMus (1914) Hvalfangsten 1913. Norsk Foskeritidende 33: 222-238.

AnOnYmus (1929) Ambrafund. Norsk Hvalfangst-Tidende 8: 224.

AnONymus (1955) Grisambol. Pamphlet published by the manufacturers Firmenich \& Cia, Geneva, Switzerland.
BACON, F. (1670) Sylva Sylvarum or a Natural History in Ten Centuries ... Published after the Author's Death By William Rawley, Doctor in Divinity, One of His Majesties' Chaplains Written by the Right Honorable Francis Lord Verulam, Viscount St. Alban, $9^{\text {th }}$ edn. London.

BANDOUIN, M. (1911) Del'existence del'Ambreen Franceet dansl'Ouest a l'époque néolithique. Revue de Bas-Poitou, 24th year: 180-188.

BEALE, T. (1839) The Natural History of the Sperm Whale. London, John Van Voorst.

BeAuregard, H. (1898) Les cryptogames de l'ambre gris. Annales de Micrographie, Paris X: 241-278.

Beauregard, H. (1901) Matière Médicale Zoologique. Histoire des drogues d'origine animale. Paris.

BEDDARD, F.E. (1900) A Book of Whales. John Murray, London.

BedDARD, F.E. (1909) Mammalia. Cambridge Natural History 10: 1-605.

Betesheva, E.I. And Akimushkin, I.I. (1955) Pitanie kashalote (Physeter catodon L.) vraione vod Kurilskoi Gryady. Trudy Instituto Okeanologii 18: 86-94.

Bosc, L.A.G. (1803) Sèche, Nouveau Dictionnaire d'Histoire Naturelle 20: 281-287.

BoviLL, E.W. (1953-54) Musk and Amber. Notes and Queries, 1953: pp. 487-9, 508-10. 1954: pp. 24-25, 69-72, 121-123, 151-154.

Boyle, Hon. R. (1673) A Letter of the Honourable Robert Boyle of Sept $13^{\text {th }} 1673$ to the Publisher, concerning Amber Greece, and its being a Vegetable Production. Philosophical Transactions, Royal Society 8: 6113-6115.

Boylston, Dr (1724) Ambergris found in Whales, communicated by Dr Boylston of Boston in New England. Philosophical Translations, Royal Society 33: 193.

Browne, SIR Thomas. (1686) Of the Spermaceti Whale. Works. Third Book, Chapter 26 in Bohn's Standard Library Edition 1880. Edit. Simon Wilkins.

Carter, H.J. (1873) On Whales in the Indian Ocean. American Magazine of Natural History 11: 231-232.

Carter, N.M. and Elsey, C.R. (1954) Ambergris found in a British Columbia Sperm whale. Progress Reports Pacific Coast Stations, Fishery Research Board of Canada 99: 35-36.

Chevalier, N. (1700) Description de la pièce D'Ambre Gris que la Chambre D'Amsterdam a recenë des Indes Orientales, pesant 182 livres; avec un petit traité de son Origine et de sa Vertu. Amsterdam, Chez l'Anteur.

Clarke, M.R., Macleod, N. and Paliza, O. (1976) Cephalopod remains from the stomachs of sperm whales caught off Peru and Chile. Journal of Zoology, London. 180: 477-493.

Clarke, R. (1949) Ambergris. Soap, Perfumery and Cosmetics 22: $147-149$.

ClARKE, R. (1954a) A great haul of ambergris. Nature, London, 174: 155-156.

Clarke, R. (1954b) Open boat whaling in the Azores: the history and present methods of a relic industry. Discovery Reports 26: 281-354.

Clarke, R., Paliza, O. and Aguayo L., A. (1988) Sperm whales of the Southeast Pacific. Part IV. Fatness, food and feeding. Investigations on Cetacea 21: 53-195. 
Cleyerus, A. (1689) De Ceto minore ambrophago. Ephem. Med. Phys. Germ. Acad. Nat. Curios 8: 69.

Clusius, C. (1605) Caroli Clusii Atrebatis, Aulae Cesoreae quondam Familiaris, Exoticorum Libri Decem. Leyden. (De Ambaro, pp 147-149).

CoLE, H.I. (1922) Identification of Ambergris. Philippine Journal of Science 20: 105-109.

Collin-Asselineau, C., Lederer, E., Mercier, D. and Polonsky, J. (1950) Sur quelques produits d'oxydation et de dégradation de l'ambréine; obtention de substance à odeur ambrée. Bulletin Societé Chimique de France, année 1950: 720-728.

Colnett, Captain James. (1798) A Voyage to the South Atlantic and round Cape Horn into the Pacific Ocean for the purpose of extending the Spermaceti Whale Fisheries. London, W. Bennett. (edition 1968).

Crosse, H. (1863) Sur l'origine de l'Ambre gris. Revue et Magasin de Zoologie 15: 244- 248 (Reprinted from Journal de Conchyliologie, 1863).

Cuvier, Monsieur F. (1836) De l'Histoire Naturelle des Cetacés. Paris.

DAkIN, W.J. (1933) Whalemen Adventurers. Angus \& Robertson Ltd., Australia.

DuDDLEY, (1725) An essay upon the natural history of the whales, with a particular account of the ambergris found in the spermaceti whale. Philosophical Transactions of the Royal Society, London 33: 256-269.

Edinburgh New Philosophical Journal (1833) 'Antediluvian Ambergris' 15: 398.

Encyclopaedia Brittanica. 1953 edition. Ambergris. I: 739.

FaWKener, W. AND LoRds of the Committee of Council. (1791) On the Production of Ambergris. Philosophical Transactions of the Royal Society 81: 43-47.

Fraser, F.C. (1952) Handbook of R.H. Burne's cetacean dissections. British Museum (Natural History), London.

Gadow, H. (1901) Amphibia and Reptiles. Cambridge Natural History 8: 443 and 445.

GAtTefossé, J. (1920) L'A Ambre Gris. Son Origine et son Histoire. La Parfumerie Moderne 12: 259-273.

Guibourt, N.J.B.G. (1876) Histoire naturelle de Drogues Simples, Paris. 4 vols. $7^{\text {th }}$ edn. (Ambergris 4: 118-123).

Hasslauer, V. (1921) Observations sur l'Ambre Gris. La Parfumerie Moderne 3: 56-58.

Hasslauer, V. (1947) Ambergris in perfume extracts. Drug and Cosmetic Industry 61: 458-460, 555-557.

Haupt, P. (1907) Jonah's Whale. Proceedings of the American Philosophical Society, Philadelphia 46: 151-164. (Ambergris p. 158).

HAWKINS, SIR RICHARD. (1593) [The Observations of Sir Richard Hawkins, Knight, in his Voyage into the South Sea] from Purchas, His Pilgrimes, 1625 edn Maclehose, Glasgow 1905, 17: 85.

IvASHIN, M.V. (1963) Ambra. Zoologicheski Zhurnal 42: 1099-1103.

Ivashin, M.V. (1966) Ambergris and sperm whale hunting. Piroda 7: 90-93.

JANISTYN, H. (1947) Ambergris -its Properties and Constitution. Soap, Perfumery and Cosmetics. February 1947: 142-143.
JanistYn, H. (1956) Ambergris. Drug and Cosmetic Industry 79: 322-325, 394-396.

Jenkins, J.T. (1932) Whales and Modern Whaling, Witherby, London [Ambergris p. 110].

Johnson, S. (1765) A Dictionary of the English Language 2 vols. London ( $3^{\text {rd }}$ edn).

Josselyn, J. (1672) New England's Rarities Discovered....., London. (Ambergris p. 36).

KAEMPFER, E. (1727) The History of Japan ..., translated by J.G. Scheuchzer from the High-Dutch. (Ambergris 1: 133).

KamimuRA, S. (1953) Japanese Whaler in Singapore. South China Morning Post, 11 November 1953.

KERR, R. (edit.) (1718) A General History and Collection of Voyages and Travels. Republished 1811-24, Edinburgh. (Ambergris vol. 1, chap. IV, p. 47).

Klobius, J. (1667) Historia Ambrae. Review in Philosophical Transactions of the Royal Society 1: 538.

LACÉPÈDE, B.E.G. Comte de (1804) Histoire naturelle des Cétacées 2 vol., Paris. (Ambergris, vol. 2: 75-94).

Lambertsen, R.H. And Kohn, B.A. (1987). Unusual multisystematic pathology in a Sperm whale bull. Journal of Wildlife Diseases 23: 510-514.

Lederer, E. (1949) Chemistry and Biochemistry of some Mammalian Secretions and Excretions. Journal of the Chemical Society, Part 3: 2115-2125.

Lederer, E. (1953) Chimie de l'ambréine. Industrie de la Parfumerie 8: 189-197.

LEE, P.G. (1994) Nutrition of cephalopods: fueling the system. Marine and Freshwater Behaviour and Physiology 25: 35-51.

Magnus, Albertus. (1280) Beati Alberti Magni, Ratisbonensis Episcopi, ordinis praedicatorum, de Animalibus Lib. XXVI..... Edition 1651. (Ambergris VI: 650).

Magnus, Olaus (1555) Olai Magni Gentium Septentrionaliú historiae breviarium. Lugd. Batavorum, 1652, pp. xii, 611 (73). (Lib.xxi, p. 578. 'De Spermate Ceti, quod Ambra dicitur et ejus medecinis).

Matthioli, P.A. (1558) 'Commentarii secundo aucti, in libros sex Pedacii Dioscoridis Anazarbei de Medica Materia: adiectis quamplurimis plantarum, \& animalium imaginibus .....' Venetiis (Ambari historia varia I, p. 47).

Maury, M.F. (1852) Explanations and sailing directions to accompany the wind and current Charts. Washington. 4th edition, pp. 413, 13 plates, 10 maps. (Ambergris, p. 244).

Murdoch, W.G.B. (1917) Modern Whaling and Bear Hunting. London.

MuRPHY, R.C. (1933) Floating Gold. Natural History 33: 117-130, 303-310.

Neumanno, C. (1734) De Ambra Grysea. Philosophical Transactions of the Royal Society 33: 344-370, 371-402, 417-437.

OHLOFf, G. (1955) The Odoriferous Principles of Ambergris and the Synthetic Ambropur Dragoco. Dragoco Berichte 8: 129-132.

Olmsted, F.A. (1841) Incidents of a Whaling Voyage. New York.

Ommaney, F.D. (1938) South Latitude. Longmans, Green \& Co., London. 
PARrY, E.J. (1925) Parry's Cyclopaedia of Perfumery. 2 vols. London.

PARRY, E.J. (1937) Ambergris. Page 303 in Thorpe's Dictionary of Applied Chemistry, 4th edition, London.

Peelle, M.L. (1932) Whaling in northeastern Japanese waters. Science 75: 666-667.

Pelletier, P.S. and Caventon, J. (1820) Sur la nature de la substance adipocireuse de l'ambre gris et sur l'origine de ce produit. Journal de Pharmacie, Paris, 6: 49-58.

Polo, Marco, the Venetian. Travels, 1271-1295. Edition 1906, edit. John Masefield.

Pomet, P. (1694) Histoire Générale des Drogues... Paris. (Ambergris, $2^{\text {nd }}$ part, pp. 57-60).

Pouchet, G. (1892) Sur les calculs intestinaux du Cachalot (ambre gris). Comptes Rendus l'Acádemie des Sciences 114: 1487-1489.

Pouchet, G. (1893a) Contribution à l'histoire du spermaceti. Bergens Museum Aarbog 1: 1-25.

Pouchet, G. (1893b) Sur l'ambre gris. Extrait du volume commémoratif du centenaire de la fondation du Muséum de Histoire Naturelle, Paris, pp. 17.

Pouchet, G. AND BeAuregard, M.M. (1892) Note sur l'ambre gris. Comptes Rendues du Societé Biologique. 9th series, 4: 588-590.

Purchas, S. (1625) Hakluytus Posthumus or Purchas, his Pilgrimes. Edn 1905-7, 20 vols, Glasgow.

Raoul, W., Iachan, A. and Gottlieb, O.R. (1952). O Ambar Cinzento. Revista de Química Industrial 21 (238): 18-22.

RATCLIFFe, H.L. (1942) Autopsy of a male pygmy sperm whale (Kogia breviceps). Notulae Naturae Philadelphia 112, pp. 4.

Riban, J. (1912) Sur l'Ambréine. Comptes Rendues de l'Académie de Sciences, 154: 1729-1732.

Rochefort, C. DE (1658) Histoire Naturelle et Morale des Iles Antilles de l'Amérique. Rotterdam. (Ambergris in ch. 20).

Ruud, J.T. 1937. Spermhvalen, Physeter catodon (Linné). Norsk Hvalfangst Tidende 11: 418-428.

Sammons, H.G., Vaughan, D.J. and Frazer, A.C. (1956) Synthesis of Long-Chain Fats by Bacteria isolated from Human Faeces. Nature, London 177: 237.

Schmidt-Nielsen, S. AND Flood, A. (1936) Zur Kenntnis des Ambers. Kongelige Norsk Videnskabers Selskab 9 (2): 5-8.

Schwediawer, Dr. (1783) An Account of Ambergrise.
Philosophical Transactions of the Royal Society 73: 226-241.

Sibbaldus, R. (1692) Phalainologia Nova; sive Observationes de Rarioribus QuibusdemBalaenis in Scotiae Littus nuper ejectis... Edinburgh, Second Impression 1773 [Ambergris pp. 98-104]

SOUTHWELL, T. (1881) Seals and Whales of the British Seas. Jarrold \& Sons, London. (Ambergris p. 93).

STIRLING, A.C. (1934) The romance of ambergris. Chemist and Druggist 120: 294-295.

Stoll, M. (1954). Recherches sur l'ambre gris et son parfum. Industries de la Parfumerie 9: nos. 1 and 2: 4-6, 48-50.

SuzuKI, M. (1925) Uber die Natur der Ambra und ihoe Bestandteile. Japanese Journal of Medical Science 2 Biochemistry I: $31-42$.

Thomas, H.K. (1955) Ambra grisea. Dragoco Berichte 8: 124-128.

TIXIER, R. (1953) Sur quelques pigments tétrapyrroliques provenant d'animaux marins. Mémoires du Musée National d'Histoire Naturelle, Série A, Zoologie 5: 41-132.

TomiLIN, A.G. (1967) Cetacea. Vol. 9 in Mammals of the U.S.S.R. and Adjacent Countries (Israel Program for English Translation) (Ambergris p. 367).

Tønnessen, J.N. (1962) A Great Work on Whales. Norsk Hvalfangst-Tidende 2: 473-480.

TønNessen, J.N. (1967) Verdenfangsten 1883-1924. Vol. 2 in Den Moderne Hvalfangst Historie. Norsk Hvalfangstforbund, Sandefjord. (Ambergris p. 484).

Van Beneden, P.J. and Gervais, P. (1880) Ostéographie des Cetacés Vivants et Fossiles Comprenant la Description...leur histoire naturelle. Arthus Bertrand, Paris.

VerRiLL, A.H. (1916) The real story of the whaler. Appleton \& Co., New York and London.(Ambergris p. 21).

VireY, J.-J. (1803). Ambre gris. Vol. I (A-APA), pp. 297-302. in Nouveau Dictionnaire d'Histoire Naturelle, Paris.

Vogel, M. (1820) Examen d'une concrétion biliaire, suivi d'observations sur la nature de l'ambre gris. Journal de Pharmacie, Paris 6: 215-218.

Vogt, C. (1884). Les Mammiferes, Paris. (Ambergris p. 287).

Yamada, M. (1954). Some Remarks on the Pygmy Sperm Whale, Kogia. Scientific Reports of the Whales Research Institute, Tokyo 9: 37-58.

ZelL, T. (1917) Die Entstehung des Ambers. Handweiser für Naturfreunde, Stuttgart 14: 324-325. 